\title{
The Value of Intraoperative Endoscopy and Manometry in the Surgical Treatment of Achalasia
}

\author{
Lucian Pripisi', Petre Hoara ${ }^{2}$, Adrian Constantin², Dragos Predescu ${ }^{2}$, Rodica Birla ${ }^{2}$, Cristina Gindea ${ }^{2}$, \\ Andrei Caragui', Silviu Constantinoi ${ }^{2}$ \\ ${ }^{1}$ CF2 Clinical Hospital, Bucharest, Romania \\ 'General and Esophageal Surgery Clinic, Center of Excellence in Esophageal Surgery, "Sf. Maria” Clinical Hospital, Bucharest, Romania
}

Corresponding author:

Petre Hoara, MD

General and Esophageal Surgery

Clinic, Center of Excellence in

Esophageal Surgery,

Sf. Maria Clinical Hospital, Bucharest

E-mail: petre_hoara@yahoo.com

Received: 10.02 .2018

Accepted: 12.03 .2018

\section{Rezumat}

Importanța endoscopiei și manometriei pre- și intraoperatorii în chirurgia acalaziei

Introducere: Acalazia este cea mai cunoscută tulburare de motilitate esofagiană. Tratamentul, medical, endoscopic sau chirurgical, deşi paleativ, oferă pacienților perspectiva unei vieți normale. Studiul nostru a încercat să arate rolul endoscopiei si manometriei pre şi intraoperatorii în îmbunătătirea evoluției pacienților tratați chirurgical.

Material şi metodă:A fost efectuat un studiu retrospectiv a unui lot de pacienți diagnosticați cu acalazie şi tratați chirurgical în clinica de chirurgie generală şi esofagiană, $\mathrm{Sp} \mathrm{Cl}$ „Sf Maria” din Bucureşti, între 2013-2017. Obiectivul acestui studiu a fost evaluarea eficacității imediate şi pe termen lung a miotomiei laparoscopice Heller asociată cu hemifundoplicatură Dor, cu control intraoperator prin manometrie şi endoscopie. Eficiența imediată a fost verificată comparând scorul Eckardt, presiunea SEI (sfincter esofagian inferior si vectorul volum al SEI, înainte şi după operație. Rezultate: În total, 47 de pacienți au beneficiat de tratament chirurgical pentru acalazie între 2013 şi 2017. 7 pacienți au fost tratați inițial prin altă metodă, fie dilatație endoscopică, fie miotomie sau stent. 39 pacienți au fost operați laparoscopic, la 30 pacienți s-a efectuat endoscopie intraoperatorie iar la 22 mano- $^{-}$ metrie esofagiană intraoperatorie. Postoperator s-a constatat îmbunătățirea scorului Eckardt, (de la 6,5 la 1,26, p<0,001), o scădere semnificativă a presiunii SEI (de la $18,5 \mathrm{mmHg}$ la 7 $\mathrm{mmHg}, \mathrm{p}<0,001)$. Morbiditatea a fost de 2,12\% iar la distanță au fost 1 caz de recidivă şi 2 cazuri cu esofagită. 
Concluzii: La ora actuală, miotomia Heller pe cale laparoscopică, asociată cu o hemifundoplicatură anterioară Dor, este o indicație standard în acalazie. Utilizarea endoscopiei intraoperatorii este recomandată iar manometria intraoperatorie poate aduce informații suplimentare despre eficiența miotomiei. Tratamentul chirurgical al acalaziei trebuie efectuat în centre specializate, cu experiență.

Cuvinte cheie: chirurgia acalaziei, endoscopie şi manometrie intraoperatorie

\begin{abstract}
Introduction: Achalasia is the most common esophageal motility disorder. So far, the treatment, which can be medical, endoscopic or surgical, provides only symptomatic relief. However, this can grant a normal life to the patients. We focused our study on the value of pre- and intraoperative endoscopy and manometry for improving outcome of surgical treatment.

Material and method: This is a retrospective chart review of a cohort of patients diagnosed with achalasia at St Mary Clinical Hospital, Bucharest between 2013 and 2017. The objective of this study was the assessment of the immediate and long term efficacy of laparoscopic Heller myotomy associated with Dor anterior fundoplication, intraoperative endoscopy and intraoperative manometry, as well as the assessment of late post-operative complications. The diagnosis of achalasia was based on symptoms, barium esophagogram, upper endoscopy and esophageal manometry. The immediate efficacy was assessed by comparing Eckhart score, LES pressure and LES vector volume before and after surgery.

Results: In total, 47 patients, had surgical treatment for achalasia between 2013 and 2017. For 7 patients who failed prior endoscopic or surgical, this was the second therapeutic intervention. 39 patients underwent laparoscopic surgery, 30 patients had associated intraoperative endoscopy and, 22 patients had associated intraoperative manometry. There was a significant improvement in mean Eckardt score (from 6,5 to 1,26, p<0,001), mean LES pressure (from 18,5 $\mathrm{mmHg}$ to $7 \mathrm{mmHg}$, $\mathrm{p}<0,001)$. Morbidity was $2,12 \%$ and we have had 1 recurrence and 2 postoperative esophagitis.

Conclusions: At present, laparoscopic Heller myotomy with an anterior Dor fundoplication, is a standard indication in achalasia, proving its efficiency and safety. Intraoperative use of endoscopy is recommended and intraoperative manometry may provide additional information on the effectiveness of myotomy. Surgical treatment of achalasia should be performed in specialized, experienced centers.
\end{abstract}

Key words: achalasia surgery, intraoperative endoscopy and manometry

\section{Introduction}

Although a rare condition with an incidence 1/ 100,000 population, achalasia is the most com- $^{-}$ mon esophageal motility disorder. Regarding ethiopathogenesis, it is widely accepted that autoimmune abnormalities drive abnormalities of the esophageal peristalsis and the lower esophageal sphincter (LES). Thus, achalasia is defined by the absence of esophageal pump function and by the inability LES to relax after swallowing which lead to the occurrence of dysphagia and regurgitation as main symptoms. The retrosternal pain is probably caused by spastic, non-peristaltic and non-functional contractions of the distal esophagus as an attempt to propel the esophageal content into the stomach beyond the LES barrier. Weight loss can be a long time effect of the esophageal dysmotility. These four symptoms - dysphagia, regurgitation, retrosternal pain and weight loss are included in a clinical (Eckardt) score, 
a very useful tool for diagnosis and posttherapeutic follow-up. The treatment is considered to be successful if the posttreatment Eckardt score is $<=3$ (1).

Patients who present with dysphagia as an early symptom should undergo both upper endoscopy and barium swallow, as these two investigations complement each other. During endoscopy, biopsies should be taken if there are structural abnormalities or if eosinophilic esophagitis is suspected. Eco-endoscopy and/or computed tomography are recommended in order to exclude a mechanical cause of dysphagia. Esophageal manometry is recommended if following all these investigations there is a suspicion of a functional disorder. This will allow to definitely make or exclude a diagnosis of an esophageal pathology, allowing guidance to other specialties (2).

High resolution manometry (HRM) represents the gold standard in the investigation and diagnosis of patients with functional esophageal disorders $(3,4)$. On the basis of the parameters obtained, HRM allowed the classification of achalasia into three types. Thus, Type I achalasia is characterized by the absence of esophageal peristalsis and the incapacity of the LES to relax after swallowing, without identifying contractions of amplitude greater than $30 \mathrm{mmHg}$. Type II achalasia presents, in addition to type I, a hyperpressurisation of the esophageal body between the two sphincters, and in the case of type III achalasia, some premature spastic contractions does occur in the distal esophagus. The importance of this classification is given by the different response to the treatment methods. Thus, type II achalasia responds well to any therapeutic method, whereas in type III the response rate is lower, especially for the dilatation treatment $(5,6)$.

Achalasia treatment aims to improve the symptomatology and not cure the disease. Medical treatment, including nitrates and calcium channel blockers, may be indicated in elderly, non-surgical patients or as a temporary method until a definitive treatment is performed. Side effects and loss of effect in time make this an exceptional or backup method.
Endoscopic treatment involves several options, in order of invasiveness, botulinum toxin injection at the LES level, being the first with favorable effects for about 6 months to 1 year (7), but with the generation of local fibrosis, which makes other subsequent methods more risky; insertion of a self-expanding metallic stent (a method described by a few authors with good results on a small number of cases)(8), graduated pneumatic balloon dilatation, starting with a $30 \mathrm{~mm}$ balloon diameter, then increasing to $35 \mathrm{~mm}$ and 40 $\mathrm{mm}$, with similar effects to surgery (9) on short term, but usually requiring more than one procedure and always having in mind the risk of perforation (1-4\%), which can lead to emergency surgery (therefore, patients who are referred for dilatations should also be able to tolerate surgery). Increasingly used, derived from NOTES (Natural orifice transluminal endoscopic surgery), is Per-Oral Endoscopic Myotomy (POEM). The data published to date illustrates that POEM is very effective in shortterm management of achalasia, especially of subtype IIII, clinical success being defined by a postoperative Eckardt score $\leq 3$. Other benefits are: lowering LES pressure, improving esophageal emptying, and improving the quality of life. Several studies reported shortterm efficacy rates similar to laparoscopic myotomy and a response rate of over $90 \%(10,11)$.

It was also found that POEM is safe and effective in patients with persistent/recurrent symptoms after laparoscopic myotomy, although the clinical success rate was lower ( $81 \%$ versus 94\%) than in patients without a history of surgery $(12,13)$.

By disrupting or cutting the LES, theoretic it is eliminated one of the antireflux mechanisms. So, one of the side effects of these treatment options is GERD. The reflux can be symptomatic or found only if we look for it, using esophageal pH metry (14). After pneumatic dilatation, the rate of GERD varies from $26 \%$ to $31 \%(15,16)$. Also after POEM, the incidence of reflux, not necessary symptomatic, is quite high, reaching 50\% (17). Although the response to PPI is almost complete, the effects of long term medication are still to be evaluated (18). 
Probably referring those patients to an antireflux procedure would be a solution.

Surgical treatment, with a history dating back approximately 100 years, performed by laparotomy, thoracotomy, laparoscopy, thoracoscopy, robotic surgery, evolved from anterior and posterior myotomy (19), through myotomy, partial fundoplication and pyloroplasty (Gavriliu), to anterior myotomy without circumferential dissection of the esophagus, associating an antireflux procedure, an anterior partial fundoplication (DOR), or circumferential dissection, and the association of a Toupet posterior plication (20).

There are situations when surgical treatment is the first therapeutic option, such as:

- Patients younger than 40 years, especially male. In general, these patients will need more sessions of dilation over time, surgical treatment being definitive;

- In the case of type III achalasia, where a longer myotomy on the esophagus is required;

- After failure of endoscopic dilation therapy (after more than 3 sessions of dilation or if a resting pressure of the LES $>10 \mathrm{mmHg}$ is persistent);

- When no other options are available.

Surgical treatment can be proposed to any patient with achalasia when there are no contraindications related to the patient's age or comorbidities, after explaining the benefits and risks of each available method. It is also recommended that surgical treatment of achalasia should be performed in specialized, experienced centers $(21,22)$.

Currently, the most commonly used approach is laparoscopic, which can be done in the French position (surgeon between the patient's legs) or American, with 4 or 5 trocars, with the retractor in the epigastrum or in the right hippocondrum. Once the anterior lower esophagus has been exposed, sometimes a small anterior frenotomy is required in order to allow dissection for $3-5 \mathrm{~cm}$ in the mediastinum, with the exposure and preservation of the vagus nerve. The myotomy should be started on the lower esophagus, where the muscles are thicker and the separation of the submucosa is easier.
The length of the myotomy has always been a subject of debate, since the main risk of this operation, the perforation, is proportional to the length of the myotomy. Thus, several methods have been imagined to achieve a personalized myotomy tailored to the respective case, either by intraoperative manometry or, more recently, by using Endo FLIP (functional lumen imaging probe), a device useful for the diagnosis of functional disorders of the eso-gastric junction but still unavailable in all the centers treating achalasia (23). A 4 to $6 \mathrm{~cm}$ myotomy is currently recommended on the esophagus, intubated with a thick Faucher (50-60 $\mathrm{Ch}$ ) and $1.5^{-3} \mathrm{~cm}$ on the stomach. Myotomy can be done with the dissecting scissors, being more safe regarding the risk of electric lesions but usually accompanied by a diffuse, small but annoying bleeding, or by using the monopolar electrode with low power (higher accuracy but having the risk of mucosal current diffusion, with possible late perforation) or active cutting and coagulation devices (using either electric or ultrasound energy).

If a perforation occurs, it is imperative to recognize it immediately (followed by repairing it with 1-2 separate 4.0 or 5.0 resorbable sutures) or before the end of the operation, using a test of mucosal integrity (either by introducing air in the esophagus submerged in liquid or by administering methylene blue on the Faucher or Levin probe).

It is recommended to associate a partial gastric fundoplication to lower the incidence of postoperative reflux (although some authors recommend Nissen procedure as being the most effective way of preventing reflux) $(24,25)$, as this might be superiority of laparoscopic surgery over POEM (26).

Choosing the type of fundoplication depends on the surgeon and possibly on the intraoperative conditions (for example, in the case of a mucosal perforation, the repair suture is recommended to be covered with gastric serosa through an anterior Dor fundoplication). The method is easier than Toupet and, by keeping the posterior attachments of the eso-gastric junction intact, modifies less the local anatomy.

Dividing the short gastric vessels is optional, 
depending on the intraoperative conditions, for example if the fundoplication cannot be done without tension.

Intraoperative endoscopy is very useful and can be used from the beginning, allowing the myotomy to be performed under visual control, by transilumination, and by insufflation, making it easier to identify the mucosa that protrudes between the sectioned muscle fibers. It also allows the evaluation of the length of the myotomy on the stomach, the identification of the eso-gastric junction being easier at the mucosa level. At the end, air insufflation under liquid level helps to identify potential mucosal perforations, and transilumination may help to identify any remaining circular muscle fibers.

\section{Objectives}

The main objective was to assess the immediate efficacy post-surgery by checking the improvement of (a) the Eckhart score, (b) LES pressure and (c) LES vector volume. Other objectives were assessment of term efficacy (one year post-surgery) and assessment of immediate and late post-operative complications.

\section{Methods}

This is a retrospective chart review of patients who were treated for achalasia at the General and Esophageal Surgery Clinic, St. Mary Clinic Hospital, Bucharest between 2013 and 2017. The diagnosis of achalasia was based on history and Eckhart score. As part of presurgical assessment, patients underwent barium esophagram, upper endoscopy (Olympus GIF 160) and esophageal manometry.

Esophageal manometry was performed using a low compliance, pneumohydraulic water infusion system (Mui Scientific, Mississauga, Ontario, Canada) and an eightchannel water-perfused manometry catheter (Albyn Medical). The recording sites were connected to eight external pressure transducers and the signal was processed using dedicated software (Phoenix V3 - Albyn Medical). The eight-channel catheter was introduced with the tip with four recording sites in the stomach and then manually pulled back with $0,5 \mathrm{~cm}$ steps till the tip reached the lower esophagus. Mean resting LES pressure was calculated as the mean end-expiratory LOS pressure. The program also calculated the sphincter vector volume (the volume of the 3D graphical representation of the entire LES).

After discussing the alternative, the patients received surgical treatment, laparoscopic Heller myotomy, associated with Dor fundoplication. The patient was placed in supine position with legs spread, the surgeon standing between the legs, first assistant on the left side of the patient and second assistant on the right. We use 5 ports, with the retractor usually in the epigastric region. After induction of the anesthesia, the catheter for esophageal manometry was introduced and the LES pressure and the vector volume were recorded (Fig. 1).

The catheter was then removed and a $50 \mathrm{Fr}$ Faucher was introduced, for easier identification of the esophagus and for myotomy. In the laparoscopic group, the esophagus was dissected and freed only on the anterior side, with careful preservation of the vagus nerve. The myotomy was started on the distal abdominal esophagus (Fig. 2) and carried up for about 4-6 $\mathrm{cm}$ and down the stomach $1,5-2 \mathrm{~cm}$.

After myotomy, the Faucher was removed and the intraoperative endoscopy was performed to evaluate the length of the myotomy, and to check for perforations. This was done either visually or by insufflation of air for

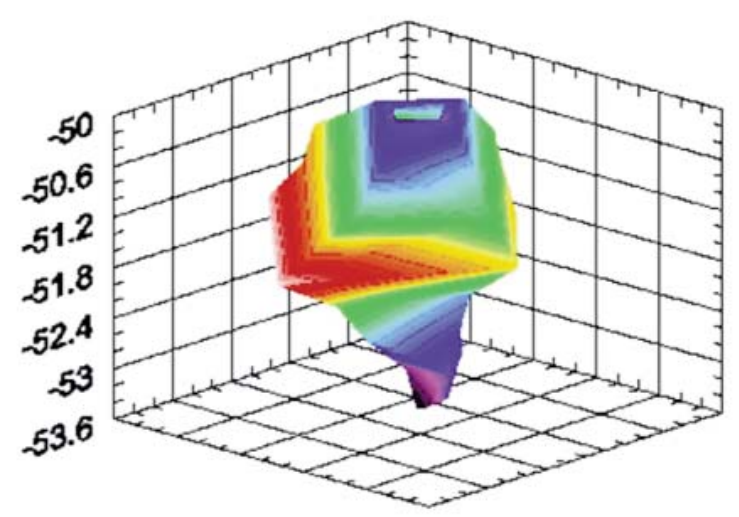

Figure 1. Intraoperative LES vector volume before myotomy 


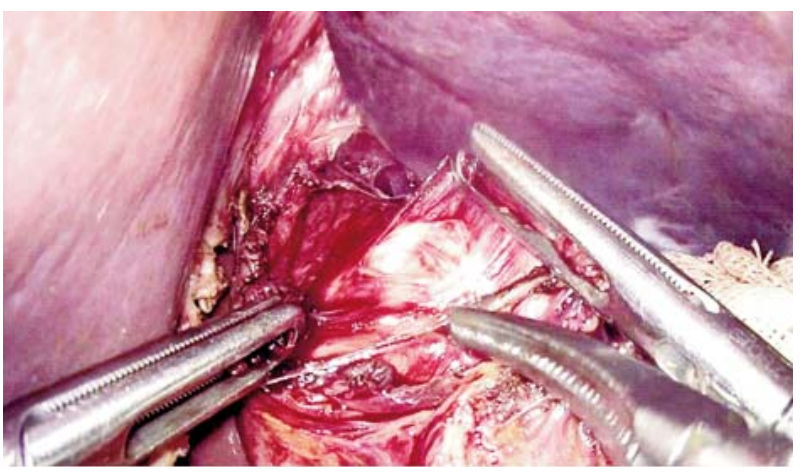

Figure 2. Starting the dissection on the lower esophagus

leakage test (the esophagus being submerged in liquid). The endoscope was passed into the stomach to evaluate the ease of passing the cardia and the length of the myotomy on the gastric side (Fig. 3).

After endoscopy, the manometry catheter was reintroduced, and the LES pressure and vector volume were measured postintervention (Fig. 4).

The patients had been followed at 3, 6 and 12 months post-surgery, then annually for three years. The Eckardt score, the esophageal manometry and the barium esophagram (the barium column height at 5 minutes) were recorded at each visit. Endoscopy was performed at 3 years post-surgery for all patients. For some patients with recurrent / persistent retrosternal pain, endoscopy was done sooner in order to exclude esophagitis.

The statistical data was analyzed using SPSS ver 23. The data were synthetized as means and standard deviations or medians and quartiles. For normality testing it was used Saphiro-Wilk.

\section{Results}

There were 47 patients with achalasia who received surgical treatment in our clinic in the past 5 years (2013-2017). The mean age was 51 years, with extremes 18 and 84, male / female ratio $1,23.7$ patients had a history of previous treatment (endoscopic dilation - 4, Heller myotomy - 2, esophageal stent - 1). The mean Eckardt score was 6,5. The percentage of patients that were operated laparoscopic

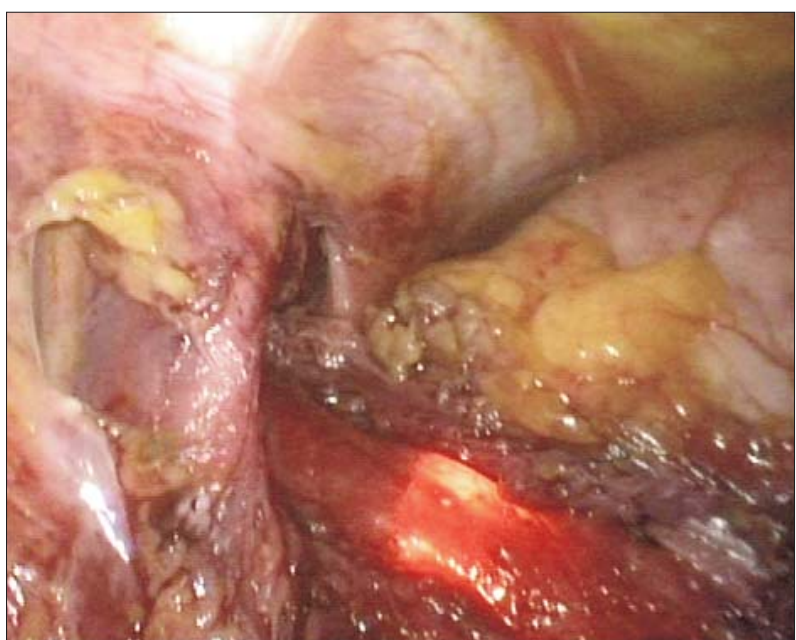

Figure 3. Intraoperative endoscopic control

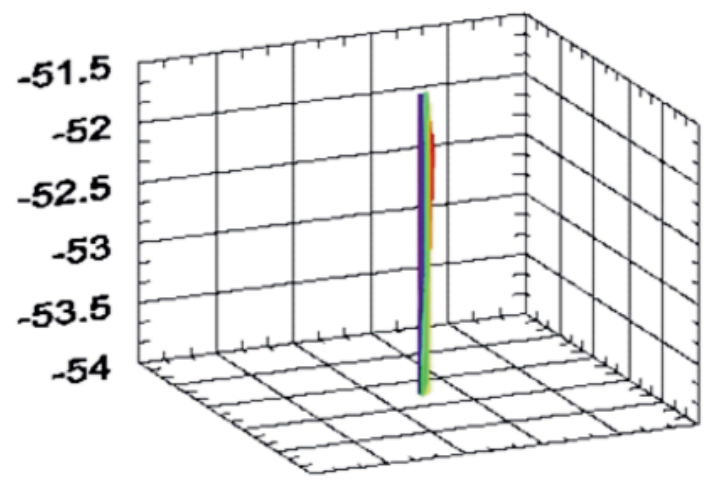

Figure 4. Intraoperative LES vector volume after myotomy

was $90 \%$ and, in the last year, we have used a 3D laparoscope in 9 patients. Intraoperative endoscopy was performed in 30 patients, and manometry in 22 patients (19 before and after myotomy), with LES pressure assessment after anesthetic induction and intubation, and then after myotomy. The length of the myotomy varied between 7 and $9 \mathrm{~cm}$, of which $1.5-2 \mathrm{~cm}$ on the stomach and in 43 cases an anterior Dor hemifundoplication was performed.

Regarding short term efficacy, surgical treatment was successful in all cases. Thus, average Eckardt's score of [mean 6,57 before surgery dropped significantlz to 1,26 $(p<0,001)]$.

Intr-operative manometry showed significant reduction in average LES pressure (from 
$18,5 \mathrm{mmHg}$ before myotomy to $7 \mathrm{mmHg}$ $(\mathrm{p}<0,001))($ Fig. 5).

Intraoperative manometry prolonged the surgery by $15-20$ minutes and we have observed that after induction of anesthesia, the LES pressure dropped, sometimes quite much. However, comparing the values before and after myotomy, the differences in LES pressure and vector volume were clear (Table 1). The results obtained influenced the surgeon's attitude in terms of extending the myotomy in 3 cases and finishing the intervention in one case.

Regarding the long term efficacy, only 1 patient $(2.12 \%)$ had recurrence of symptoms at one year post-procedure. This required one session of balloon dilation.

\section{Postoperative Complications}

Regarding peri-operative complications, there were $4(8.5 \%)$ intraoperative mucosal perforations. All were recognized in situ and repaired with separated vicryl or PDO 4.0 sutures. For these four patients, the nasogastric tube was maintained postoperatively for 4-5 days. The integrity of the esophageal mucosa was checked by radiology with a water-soluble contrast agent. The resumption of feeding was initially done with liquids only, then with semisolid food. For three patients the outcome was favorably, but one patient developed a subphrenic abscess as a consequence of an esophageal fistula. This required re-intervention with drainage, insertion of a feeding jejunostomy and a totally covered esophageal stent. The patient's recovery was slowly but favorable, as the fistula

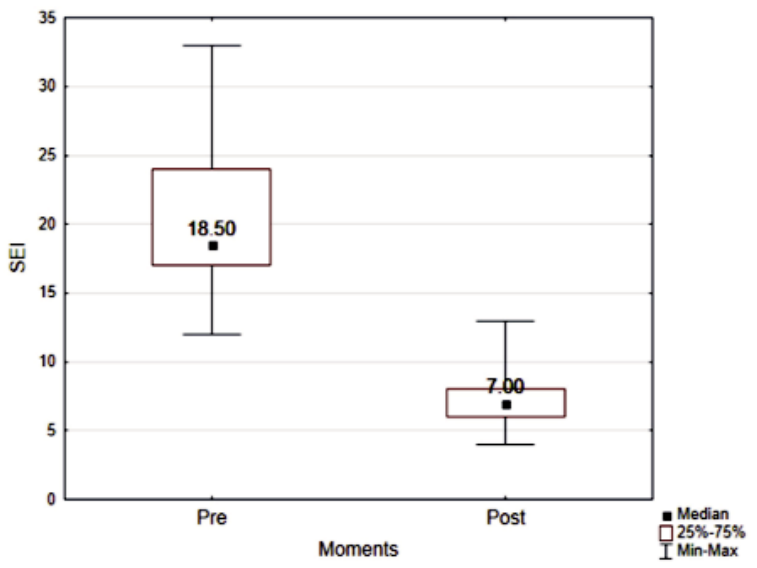

Figure 5. LES pressure before and after myotomy

closed and the removal of the stent was possible at 6 weeks after surgical intervention.

Regarding long-term complications, 2 patients $(4,25 \%)$ developed reflux esophagitis grad A (Los Angeles classification) which was diagnosed one year after surgical intervention. They have been successfully treated with proton pump inhibitors. Mortality was zero.

\section{Discussions}

The surgical treatment in achalasia is standard today, along with pneumatic dilation and the new developed POEM. After procedure, the main issues are recurrence or reflux. The pneumatic dilation is the least invasive but also the least reliable in time regarding dysphagia, with around 50-70 \% success rate after 5 years. Also reflux has an incidence of around 30\%. POEM is very effective on short time, with promising

Table 1. Intraoperative values of LES pressure and vector volume before and after myotomy

\begin{tabular}{lccc}
\hline & Before myotomy & After myotomy & $\begin{array}{c}\text { Comparative test of the values } \\
\text { (p_value) }\end{array}$ \\
\hline SEI $(\mathrm{N}=19) \mathrm{mmHg}$ & $9.16 \pm 4.4878$ & $4.47 \pm 2.1178$ & 0.000243 \\
& $9.0[5.0,11.0]$ & $4.0[3.0,6.0]$ & (Wilcoxon Signed Ranks Test) \\
\hline VV io $(\mathrm{N}=19) \mathrm{mmHg}^{2} . \mathrm{cm}$ & $1409.74 \pm 1378.9683$ & $397.11 \pm 478.1148$ & 0.000463 \\
& $969.0[321.0,1987.0]$ & $258.0[88.0 .455 .0]$ & (Wilcoxon Signed Ranks Test) \\
\hline
\end{tabular}


results on long time, but with a great incidence of reflux after the procedure, usually responding to PPI treatment. It is also less invasive on the abdominal wall but has a relatively long learning curve (between 13 and 100 cases) (27, 28). Laparoscopic Heller myotomy associated with an antireflux procedure is safe, has long term good results and seems more efficient in preventing postprocedural reflux. In our group, at one year, the recurrence rate was $2 \%$. The gastro-esophageal reflux, was found in $4 \%$ of patients, diagnosis based on clinical symptoms and upper endoscopy. We think that 24 hours esophageal $\mathrm{pH}$ monitoring may had identify a higher number of patients with pathologic reflux, but this was not available.

The limitation of the study are the relative short time of surveillance.

\section{Conclusion}

At present, laparoscopic Heller myotomy, accompanied by an anterior Dor fundoplication, is a standard indication in achalasia, proving its efficiency and safety. Intraoperative use of endoscopy is recommended and intraoperative manometry may provide additional information on the effectiveness of myotomy. Surgical treatment of achalasia should be performed in specialized, experienced centers.

\section{Acknowledgements}

We thank Mrs. Eugenia Panaitescu, Department of Informatics and Biostatistics, "Carol Davila" University of Medicine and Pharmacy, for the help provided.

\section{Conflicts of Interest}

No conflict of interest.

\section{Authors' Contributions}

All authors equal contributed to this paper.

\section{References}

1. Eckardt AJ, Eckardt VF. Treatment and surveillance strategies in achalasia: an update Nat Rev Gastroenterol Hepatol. 2011;8(6): 311-9.
2. Constantinoiu S, Constantin A, Achim F, Boeriu M. Acalazia cardiei. În: Tratat de Patologie si Chirurgie Esofagiana, sub red Constantinoiu S, Cordos I, Ciuce C, Scripcariu V. Bucuresti: Editura Academiei Romane; 2017. p. 382-395.

3. Pandolfino JE, Kwiatek MA, Nealis T, Bulsiewicz W, Post J, Kahrilas PJ. Achalasia: a new clinically relevant classification by highresolution manometry. Gastroenterology. 2008;135(5):1526-33.

4. Kahrilas PJ, Bredenoord AJ, Fox M, Gyawali CP, Roman S, Smout AJ, et al. International High Resolution Manometry Working Group. The Chicago Classification of esophageal motility disorders, v3.0. Neurogastroenterol Motil. 2015;27(2):160-74.

5. Rohof WO, Salvador R, Annese V, Bruley des Varannes S, Chaussade S, Costantini M, et al. Outcomes of treatment for achalasia depend on manometric subtype. Gastroenterology. 2013; 144(4):718-25; quiz e13-4.

6. Pandolfino JE, Gawron AJ Achalasia: a systematic review. JAMA. 2015:313(18):1841-52.

7. Ghoshal UC, Chaudhuri S, Pal BB, Dhar K, Ray G, Banerjee PK. Randomized controlled trial of intrasphincteric botulinum toxin $A$ injection versus balloon dilatation in treatment of achalasia cardia. Dis Esophagus. 2001;14(3-4):227-31.

8. Cheng YS, Ma F, Li YD, Chen NW, Chen WX, Zhao JG, et al. Temporary self-expanding metallic stents for achalasia: a prospective study with a long-term follow-up. World J Gastroenterol. 2010;16(40):5111-7.

9. Borges AA, Lemme EM, Abrahao LJ Jr, Madureira D, Andrade MS, Soldan M, et al. Pneumatic dilation versus laparoscopic Heller myotomy for the treatment of achalasia: variables related to a good response. Dis Esophagus. 2014;27(1):18-23.

10. Talukdar R, Inoue H, Nageshwar Reddy D Efficacy of peroral endoscopic myotomy (POEM) in the treatment of achalasia: a systematic review and meta-analysis. Surg Endosc. 2015;29(11): 3030-46.

11. Kahrilas PJ, Katzka D, Richter JE. Clinical Practice Update: The Use of Per-Oral Endoscopic Myotomy in Achalasia: Expert Review and Best Practice Advice From the AGA Institute. Gastroenterology. 2017;153(5):1205-1211.

12. Vivek Kumbhari and Mouen A Khashab Peroral endoscopic myotomy World J Gastrointest Endosc. 2015;7(5):496-509.

13. Uppal DS, Wang AY. Update on the endoscopic treatments for achalasia World J Gastroenterol. 2016;22(39):8670-8683.

14. Familiari P, Greco S, Gigante G, Calì A, Boškoski I, Onder G, et al. Gastroesophageal reflux disease after peroral endoscopic myotomy: Analysis of clinical, procedural and functional factors, associated with gastroesophageal reflux disease and esophagitis Dig Endosc. 2016; 28(1):33-41. doi: 10.1111/den.12511. Epub 2015 Sep 15.

15. Min YW, Lee JH, Min BH, Lee JH, Kim JJ, Rhee PL. Association between gastroesophageal reflux disease after pneumatic balloon dilatation and clinical course in patients with achalasia. J Neurogastroenterol Motil. 2014;20(2):212-8.

16. Novais PA, Lemme EM. 24-h pH monitoring patterns and clinical response after achalasia treatment with pneumatic dilation or laparoscopic Heller myotomy. Aliment Pharmacol Ther. 2010;32(10): 1257-65. doi: 10.1111/.1.1365-2036.2010.04461.x. Epub 2010 Sep 25.

17. Shiwaku H, Inoue H, Sasaki T, Yamashita K, Ohmiya T, Takeno S, et al. A prospective analysis of GERD after POEM on anterior myotomy. Surg Endosc. 2016;30(6):2496-504.

18. Eusebi LH, Rabitti S, Artesiani ML, Gelli D, Montagnani M, Zagari RM, et al. Proton pump inhibitors: Risks of long-term use. J Gastroenterol Hepatol. 2017:32(7):1295-1302. doi: 10.1111/jgh.13737.

19. Heller E. Extramuköse Cardiaplastik beim chronischen Cardiospasmus mit Dilatation des Ösophagus [German]. Mitt. Grenzgeb Med. Chir. 27, 141-145 (1913)

20. Falkenback D, Lehane CW, Lord RV. Robot-assisted oesophageal and gastric surgery for benign disease: antireflux operations and Heller's myotomy. ANZ J Surg. 2015;85(3):113-20. Epub 2014 Jul 9.

21. Patti MG, Fisichella PM. Controversies in management of achalasia. J Gastrointest Surg. 2014;18(9):1705-9.

22. Vaezi MF, Pandolfino JE, Vela MFACG clinical guideline: diagnosis 
and management of achalasia. Am J Gastroenterol. 2013;108(8): 1238-49; quiz 1250.

23. Teitelbaum EN, Soper NJ, Pandolfino JE, Kahrilas PJ, Hirano I, Boris L, et al. Esophagogastric junction distensibility measurements during Heller myotomy and POEM for achalasia predict postoperative symptomatic outcomes. Surg Endosc. 2015; 29(3):522-8.

24. Di Martino N, Brillantino A, Monaco L, Marano L, Schettino M, Porfidia R, et al. Laparoscopic calibrated total vs. partial fundoplication following Heller myotomy for oesophageal achalasia. World J Gastroenterol. 2011;17(29):3431-40.

25. Rossetti G, Brusciano L, Amato G, Maffettone V, Napolitano V, Russo G, et al. A total fundoplication is not an obstacle to esophageal emptying after Heller myotomy for achalasia results of a long-term follow up. Ann Surg. 2005;241(4):614-621.

26. Marano L, Pallabazzer G, Solito B, Santi S, Pigazzi A, De Luca R, et al. Surgery or peroral esophageal myotomy for achalasia: a systematic review and meta-analysis. Medicine (Baltimore). 2016; 95(10):e3001.

27. El Zein M, Kumbhari V, Ngamruengphong S, Carson A. K, Stein E, Tieu $A$, et al. Learning curve for peroral endoscopic myotomy Endosc Int Open. 2016;4(5):E577-E582.

28. Zhang Z L X, Zhang W, Zhang $Y$, Chen W, Qin W, Hu J, et al. Comprehensive evaluation of the learning curve for peroral endoscopic myotomy. Clinical Gastroenterology and Hepatology. 2017. doi.org/10.1016/j.cgh.2017.11.048 